\title{
ДЕЯКІ ПИТАННЯ ЩОДО ДІЯЛЬНОСТІ ТА ПЕРСПЕКТИВИ РОЗВИТКУ НЕДЕРЖАВНОГО ПЕНСІЙНОГО ФОНДУ
}

\author{
Кузніченко О. В., Дзіковська Н. Р.
}

у статті проведено аналіз сучасного стану системи недержавного пенсійного забезпечення. Проаналізовано динаміку основних показників діяльності недержавних пенсійних фондів за останні роки. Розглянуто структуру активів недержавних пенсійних фондів та напрями їх інвестування. Розглянуто динаміку кількості укладених пенсійних контрактів та кількості вкладників за останні роки. Обгрунтовано значущість функціонування недержавних пенсійних фондів для економіки та переваги для викори стання недержавних пенсійних фондів в якості інструмента для створення особистих накопичень. Проаналізоване чинне пенсійне законодавство, а саме Закон України «Про недержавне пенсійне забезпечення» від 09.07.2003 р. і Закон України «Про пенсійне забезпечення» від 05.11.1991р.

Ключові слова: пенсійна система, пенсійне забезпечення, недержавний пенсійний фонд, пенсійні активи, вне скU.

В статье проведен анализ современного состояния системы негосударственного пенсионного обеспечения. Проанализирована динамика основных показателей деятельности негосударственных пенсионных фондов за последние годы. Рассмотрена структура активов негосударственных пенсионных фондов и направления их инвестирования. Рассмотрена динамика количества заключенных пенсионных контрактов и количества вкладчиков за последние годы. Обоснована значимость функционирования негосударственных пенсионных фондов для экономики и преимущества для использования негосударственных пенсионных фондов в качестве инструмента для создания личных накоплений.

Ключевые слова: пенсионная система, пенсионное обеспечение, негосударственный пенсионный фонд, пенсионные активы, взносы.

The article analyzes the current state of the system of nonstate pension provision. The dynamics of the main indicators of activity of non-state pension funds in recent years has been analyzed. The structure of non-state pension funds assets and their investment directions is considered. The dynamics of the number of concluded pension contracts and the number of depositors in recent years has been considered. The significance of the functioning of non-state pension funds for the economy and advantages for the use of non-state pension funds as a tool for creating personal savings is substantiated.

For today, the state of the modern pension system of Ukraine is characterized that the pension system of country functions stably, pensions are paid in good time. The mechanism of periodic increase of labour pensions, based on the increase of middle salary of workers, allows to provide the increase of pensions, comparable with rates increase of acuestss busy in an economy.

One of problems, that needs a rapid and quality decision there is a considerable contribution of money to the organs that engage in the pension system. And one of methods of decision of this problem there is realization of pension reform. In the west, under pension reform, understand a transition from солідарної pension reform to the story. The accumulation of pension con-

Кузніченко О. В., Дзіковська Н. Р., 2019 sists in that everybody puts aside on the old age, on an own pension charge. Then, when this man will become old, she will get pension payments from the account. In Ukraine story pensions exist in compliance with the legislation Ukraine only as non-state pension fund.

Thus, system of the non-state pension system and her development of financial mediation, is on the stage of reformation and needs a considerable improvement, for the achievement of corresponding results. An increase of efficiency of the non-state pension system is one of basic tasks of present time and important steps of reformation of the system of the pension system in Ukraine.

Key words: pension system, pension, non-state pension fund, retirement assets, contributions.

Постановка проблеми. Сьогодні стан сучасного пенсійного забезпечення України характеризується тим, що пенсійна система країни функціонує стабільно, пенсії виплачуються своєчасно. Механізм періодичного збільшення трудових пенсій, заснований на зростанні середньої заробітної плати працівників, дозволяє забезпечувати підвищення пенсій порівняно з темпами зростання доходів зайнятих в економіці.

Аналізуючи чинне пенсійне законодавство, а саме Закон України «Про недержавне пенсійне забезпечення» від 09.07.2003 р. і Закон України «Про пенсійне забезпечення» від 05.11.1991 р., ми спостерігаємо, що в пенсійних системах держави спостерігається ряд проблем. Найбільш актуальною, за даними Саміт ООН, для прийняття Порядку денного в галузі розвитку на період після 2015 року $є$ проблема старіння населення, яка характеризується збільшенням процентної частки літніх людей (тобто осіб у віці 60 років і старше) при скороченні процентної частки дітей і населення працездатного віку. Прогноз на довгострокову перспективу показує значне скорочення числа працюючих громадян в Україні, а це $\epsilon$ критичною проблемою для солідарної пенсійної системи. На одного працюючого незабаром буде припадати два пенсіонери, що призведе до серйозного дефіциту державної пенсійної системи [1, с. 1].

Мета - провести аналіз сучасного стану системи недержавного пенсійного забезпечення.

Виклад основного матеріалу. Так, за статистичними даними 2017 року, в Україні на 2-х пенсіонерів (13,8 млн. осіб) припадало лише 3 працюючих (21 млн. осіб). Станом на початок 2018 року 12 офіційно працевлаштованих українців забезпечували пенсії 11 пенсіонерів (за даними Пенсійного фонду України). У той же час слід зазначити, що за прогнозом уряду України до 2050 року кількість пенсіонерів збільшиться у 2 рази.

Отже, однією із проблем, яка потребує швидкого і якісного рішення, $\epsilon$ значне відрахування коштів до органів, що займаються пенсійним забезпеченням. І одним із способів вирішення цієї проблеми $є$ проведення пенсійної реформи. На Заході під пенсійною реформою розуміють перехід від солідарної пенсій- 


\section{Правове забезпечення адміністративної реформи}

ної реформи до накопичувальної. Накопичення пенсії полягає в тому, що кожна людина відкладає на свою старість сама, на власний пенсійний рахунок. Потім, коли ця людина постаріє, вона отримуватиме зі свого ж рахунку пенсійні виплати. В Україні накопичувальні пенсії існують згідно із законодавством України лише у вигляді недержавних пенсійних фондів (далі - НПФ).

Наприклад, у США, в Європі немає, напевно, жодної людини, яка б не була членом НПФ. Адже НПФ - це необхідний елемент пенсійного забезпечення. НПФ мають ряд переваг перед іншими довгостроковими інструментами. По-перше, це фактично єдиний інструмент, який дає доступ виключно після досягнення пенсійного віку. Усі інші інструменти - депозити, страхування, життя, пайові фонди - дозволяють достроково розірвати договір і повернути всі кошти або їх частину (якщо договір передбачає штрафні санкції за дострокове розірвання). Пенсійний рахунок можна розірвати, заморозити (якщо більше відкладати не виходить) або перевести в інший НПФ (якщо результати роботи керуючої компанії не задовольняють) [2, с. 1].

На відміну від накопичувального страхування пенсій, де між клієнтами розподіляється $85 \%$ отриманого інвестдоходу, НПФ ділить весь прибуток, який кожен накопичував окремо. Але важливо відзначити, що, на відміну від інших фінансових інструментів (того ж страхування пенсій або депозитних рахунків), НПФ не гарантує якого $б$ то не було доходу. І якщо фонд спрацював в мінус, збитки теж ляжуть на плечі вкладників.

Якщо член фонду після досягнення пенсійного віку вирішить не забирати всю суму відразу, а захоче отримувати виплату частинами (ії розмір і періодичність вкладник встановлює самостійно), то фонд продовжить керувати цими активами і нараховувати прибуток. Слід зазначити, що під час страхування життя після закінчення терміну дії договору страхова компанія припиняє нараховувати інвестдохід. Також позитивним $\epsilon$ те, що існує ще один «бонус»: НПФ не штрафують своїх членів за невнесення або несвоєчасне внесення чергового платежу. Тільки від майбутнього пенсіонера залежить, скільки він накопичить собі на старість. Відповідно до слів Л. Діденко, якщо українець буде відкладати щомісяця по 1 тис. грн., то за 10 років він внесе в НПФ 120 тис. грн. плюс інвестдохід [3].

Станом на 30 вересня 2018 р. середній розмір пенсійної виплати в НПФ на одну особу склав 59,6 тисяч гривень, а, для порівняння, в солідарній системі середній розмір пенсії складає 2,6 тисячі гривень. У 2017 році українці в середньому відкладали по 491 гривні до НПФ.

Але $\epsilon$ у НПФ і ряд мінусів. Перший, як уже зазначалося, - відсутність гарантованого доходу. Ніхто не застрахований від того, що після закінчення терміну дії договору він отримає менше, ніж вклав за час накопичення. Також варто відзначити, що термін виходу на пенсію вкладник вибирає сам, але він не повинен відрізнятися більш ніж на 10 років від встановленого державою рівня (в більшу або в меншу сторону).

Ще один нюанс стосується порядку виплат: їх періодичність повинна бути розтягнута не менше ніж на 10 років, якщо розмір накопичень більше 60 прожиткових мінімумів для непрацездатних громадян. Із 1 травня 2017 року розмір виплати становить 1312 грн., тобто накопичення повинне бути більше 78720 грн. Тобто виплату можна отримати одноразо- во, якщо розрахункова сума щомісячної виплати пенсії протягом 10 років менше 50\% місячного прожиткового мінімуму для непрацездатних громадян.

Також фонд зобов'язаний виплатити всю суму, незалежно від іï розміру і часу звернення учасника, за наявності медично підтвердженого критичного стану здоров'я (онкозахворювання, інсульт), у разі настання інвалідності учасника фонду, виїзду учасника фонду на постійне проживання за межі України, а також у разі смерті вкладника (пенсійні кошти виплачуються його спадкоємцям) [2].

Другим і головним недоліком НПФ $є$ те, що вони за законодавством працюють тільки з гривнею. Тобто в періоди жвавої девальвації гривні або високої інфляції вкладник фонду може втратити частину своїх заощаджень - вони просто знеціняться. Утім, НПФ можуть інвестувати у валютні інструменти. В Україні навіть $\epsilon$ кілька фондів, які інвестують виключно у валютні інструменти (депозити у валюті, валютні ОВДП), що захищає вкладення від ризику девальвації. Але в ряді випадків такі фонди показують результати гірше інфляції [3, с. 30-44].

В Україні НПФ існують із 2004 року, проте особливої популярності вони не здобули. Їх членами є 836,2 тис. осіб - це майже у два рази менше, ніж кількість українців, які мають довгострокові договори страхування життя. В останні два роки кількість пенсійних рахунків практично не змінилася, хоча п'ять років тому кількість учасників була на 43\% менше. Самих НПФ стало майже на чверть менше, пенсійні рахунки із закритих фондів згідно із законом повинні бути переведені в інші НПФ, що працюють на ринку (див. Табл. 1).

Таблиця 1

Динаміка кількості учасників недержавних пенсійних фондів

\begin{tabular}{|c|c|c|c|}
\hline & $\begin{array}{c}31 \text { березня } \\
2015 \text { року }\end{array}$ & $\begin{array}{c}31 \text { березня } \\
2016 \text { року }\end{array}$ & $\begin{array}{c}31 \text { березня } \\
2017 \text { року }\end{array}$ \\
\hline $\begin{array}{c}\text { Загальна } \\
\text { кількість } \\
\text { учасників, } \\
\begin{array}{c}\text { тис. } \\
\text { Осіб }\end{array}\end{array}$ & 833,6 & 830,2 & 836,2 \\
\hline
\end{tabular}

62,3\% вкладників НПФ - українці віком від 25 до 50 років. Але $\epsilon$ серед учасників пенсійних фондів особи від 50 до 60 років $(26,7 \%)$, старше 60 років $(9 \%)$ і молодше 25 років (2\%) [4].

Найбільш успішними для НПФ були 2005-2008 роки від моменту появи НПФ в Україні до початку фінансової кризи. Великі підприємства і професійні об'єднання засновували свої НПФ. Зараз, за даними Української асоціації інвестиційного бізнесу, існує 7 корпоративних НПФ і 6 професійних. Наприклад, існує НПФ Стиролу, Укртелекому, Укрексімбанку. Свій НПФ $\epsilon$ навіть у Нацбанку. А деякі організації відкривали для своїх працівників рахунки в відкритих НПФ. Внески до Фондів платили або роботодавці (ця опція включалася в соцпакет), або самі працівники, або і ті й інші, за бажанням. На рахунку фонду було і зростання фінансових ринків це дозволяло заробляти надприбутки, що приваблювало нових клієнтів [5, с. 408].

В Україні все змінилося під час фінансової кризи 2008-2009 років. Фінансові ринки обвалилися, а роботодавці скоротили бюджети на соцпакети: внески в НПФ 
стали одними з перших, які потрапили «під скорочення». У результаті велика частина з майже 850 тис. рахунків заморожена. 3 існуючих на ринку більш ніж сотні НПФ до 2017 року «дожили» лише 64.

За оцінками учасників ринку, активними $є$ трохи більше 57 тис. рахунків, які відкрили самі фізичні особи, і вони ж самостійно сплачують за себе, а також невелика частина рахунків, відкритих роботодавцями. Тому вкладення в інструменти з фіксованою прибутковістю - депозити, ОВДП, облігації - це норма. Однак частина коштів все-таки вкладається в акції. І цей факт зіграв з українськими фондами злий жарт: після кризи 2008 року акції почали стрімко знецінюватися, а знайти покупців на більшу частину акцій стало просто неможливо. У результаті активи залишилися «мертвим вантажем», який керуючим довелося згодом списати, зафіксувавши втрати.

Непоодинокими були й випадки, коли під час зростання ринку керуючі перепродували акції один одному, підвищуючи ціну активів і фіксуючи прибуток. Із приходом кризи ці махінації розкрилися. Ризиковим виявилися і інвестиції в корпоративні облігації: ряд емітентів збанкрутували, залишивши інвесторів ні з чим [6, с. 1-15].

Ще частина коштів фондів втратилася в банках-банкрутах. Засоби НПФ виплачуються в останню, сьому чергу. Поки на цю категорію вкладників вистачило коштів лише в декількох банках із 90, визнаних неплатоспроможними. Згідно із законом захист інтересів вкладника забезпечується розподілом функцій адміністратора фонду, зберігача та керуючого активами в трьох незалежних компаніях. Адміністратор фонду веде облік пенсійних рахунків, хранитель «зберігає» гроші клієнтів згідно з наданим адміністратором списками. Хранителем виступає виключно банк (ст. 44 Закону України «Про недержавне пенсійне забезпечення»). Він контролює операції 3 активами, правильність розрахунку вартості одиниці пенсійних активів і не проводить операції з активами, які не відповідають вимогам профільного закону: хранитель несе за це відповідальність. А керуючий активами відповідає за інвестування акумульованих коштів.

На думку К. Савченко, зовнішній контроль діяльності НПФ здійснюється відповідно до ст. 67 Закону України «Про недержавне пенсійне забезпечення» від 09.07.2003 р., згідно з яким держава гарантує дотримання законодавства з метою захисту майнових прав і законних інтересів учасників недержавного пенсійного забезпечення шляхом здійснення нагляду та контролю за відповідними державними органами. Кращий контролер діяльності НПФ - це сам учасник, який за бажанням може перевести свої заощадження з фонду, який його не влаштовує, в будь-який інший фонд, що працює на ринку. Хоча на практиці така поведінка - рідкість. 3 одного боку, все управління здійснюється публічно, вся звітність фонду знаходиться у відкритому доступі. Більш того, законом передбачена така структура, як рада фонду, з якої учасники НПФ делегують своїх представників. Але рада фонду часто перетворюється на формальну структуру, яка працює на громадських засадах і ніякої відповідальності за прийняті рішення не несе [7, с. 129-133].

На думку К.П. Штепенка, учасники ринку вже давно ініціювали можливість щоденного розрахунку і публікації чистої вартості одиниці пенсійних внесків. Так, кожен вкладник зможе в режимі онлайн контролювати, як змінюється сума заощаджень у нього на рахунку. Клієнторієнтована НПФ, наприклад, такі як НПФ
«Династія» або НПФ «Емеріт-Україна», надають будьякі способи доступу до інформації (щоденне розкриття інформації на сайті, доступ до електронного кабінету, SMS-розсилка і публікація щомісячної звітності про операції з активами фонду) [8, с. 1006-1010].

Згідно з рейтингом відкритості НПФ, за результатами попереднього року, серед лідерів ринку - «Лаурус» (КУА «Озон Капітал»), «ОТП Пенсія» (ОТП Капітал), «Столичний резерв» (КУА «Національний резерв»), «Династія» (КУА «Інвестиційний Капітал Україна»), «Емеріт-Україна» (КУА «Трійка Діалог Україна») [8, с. 1000-1010].

Керуючі активами НПФ сподіваються на краще останнім часом усе більше українців самостійно відкривають рахунки і регулярно платять внески. Поступово буде відновлюватись і довіра до ринку. У першу чергу, цьому сприятиме консолідація НПФ. Вже протягом року фонди з активами менше 1 млн. грн. шукають покупців: їх будуть поглинати більші гравці.

Висновки. Отже, система недержавного пенсійного забезпечення та розвиток фінансового посередництва знаходяться на етапі реформування і потребують значного вдосконалення для досягнення відповідних результатів. Підвищення ефективності недержавного пенсійного забезпечення $\epsilon$ одним із основних завдань сьогодення і важливим кроком у реформуванні системи пенсійного забезпечення в Україні.

\section{Література}

1. Цілі сталого розвитку 2016-2030 / Саміт ООН для прийняття Порядку денного в галузі розвитку на період після 2015 року. Нью-Йорк. 2015. С. 1-2. URL : http:// www.un.org.ua/ua/tsili-rozvytku-tysiacholittia/tsilistaloho-rozvytku.

2. Про недержавне пенсійне забезпечення: Закон України від 09.07.2003 № 1057-IV. URL : http:// search.ligazakon.ua/l_doc2.nsf/link1/T031057.html.

3. Діденко Л. Система недержавного пенсійного забезпечення і розвиток фінансового посередництва в Україні. Збірник наукових праць Національного університету державної податкової служби України. 2016. № 1. С. 30-44.

4. Накопич собі сам: чи $\epsilon$ альтернатива державній пенсії. URL : https://news. finance.ua/ua/news/-/404740/ nakopych-sobi-sam-chy-ye-alternatyva-derzhavnij-pensiyi.

5. Портфельне інвестування : навч. посібник / А.А. Пересада та ін. Київ : КНЕУ, 2004. 408 с.

6. Підсумки розвитку системи недержавного пенсійного забезпечення станом на 31.12.2016 / Офіційний сайт Національної комісії, що здійснює державне регулювання у сфері ринків фінансових послуг. URL : https:// nfp.gov.ua/files/17_Dep_Repetska/NPF_IV_kv\%202016.pdf.

7. Савченко К. Недержавні фонди цільового призначення в системі реалізації стабілізаційної політики в Україні. Вісник СумДУ. Серія «Економіка». 2012. № 1. C. $129-133$.

8. Штепенко К.П. Аналіз діяльності недержавних пенсійних фондів в Україні. Молодий вчений. 2016. № 12.1(40). С. 1006-1010.

Кузніченко О. В., кандидат юридичних наук, доцент, доцент кафедри цивільно-правових дисциплін Одеського державного університету внутрішніх справ

Дзіковська Н. Р., курсант Одеського державного університету внутрішніх справ 